
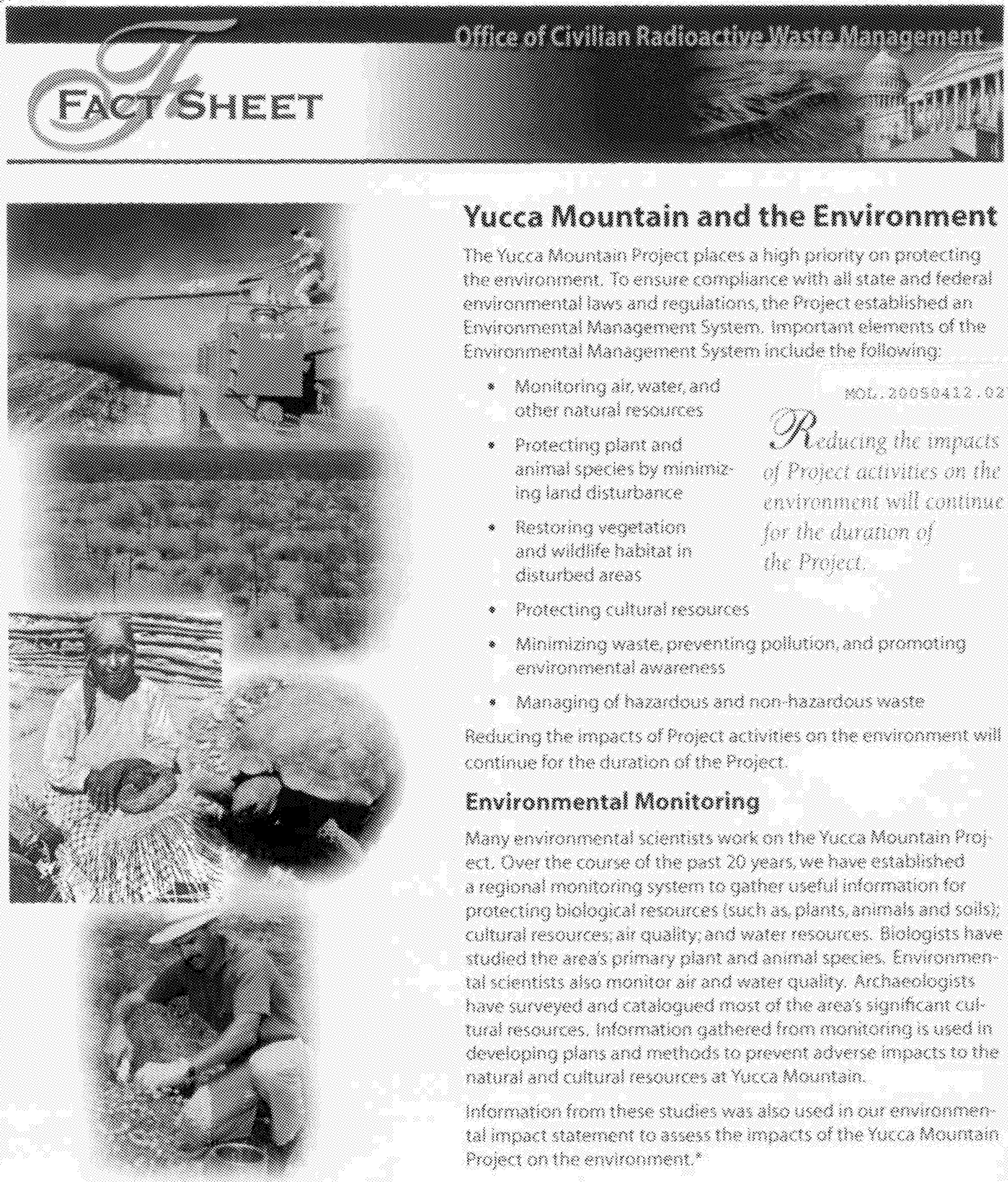

\title{
Yucca Mountain and the Environment
}

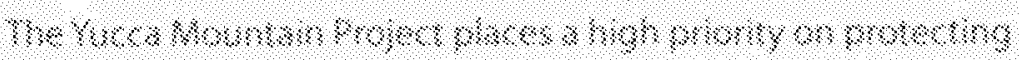

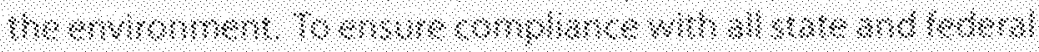

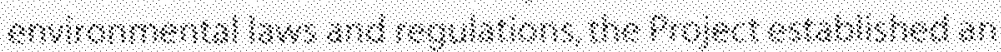
\&

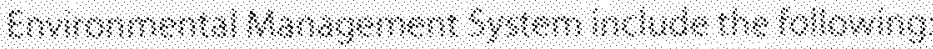

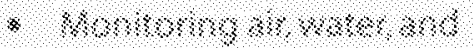
Q

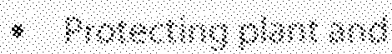

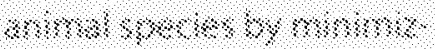

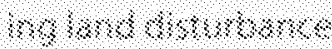

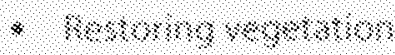

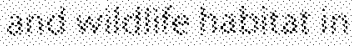

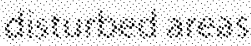

\%०.<smiles>CC1CCCC1</smiles>

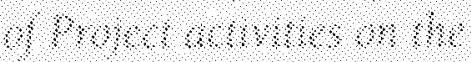

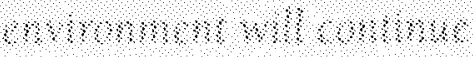

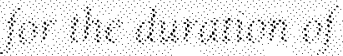
१० $1 \%, \% ०$ :

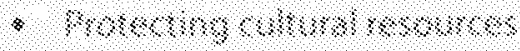

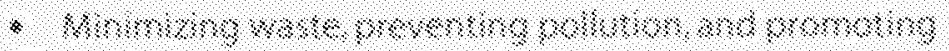
\%:

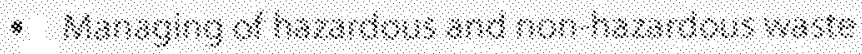

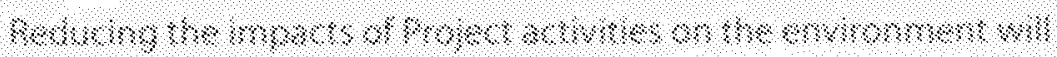
(4)

\section{Environmental Monitoring}

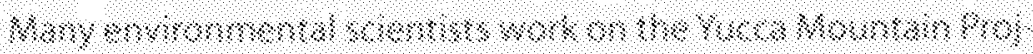

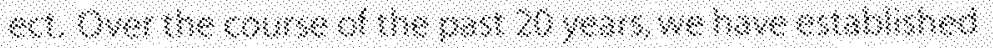

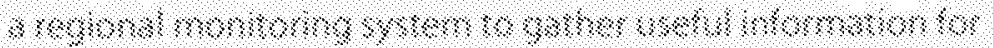

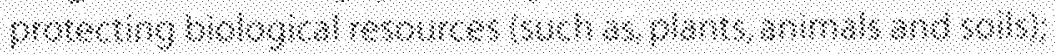

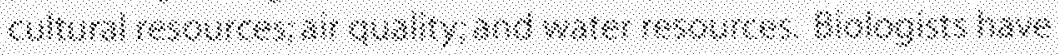

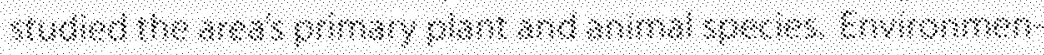

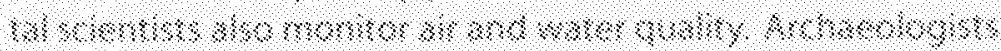

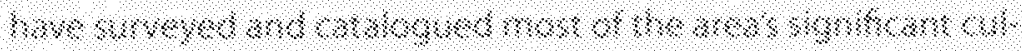

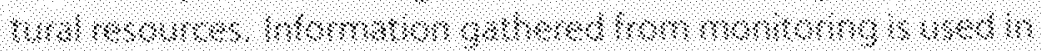

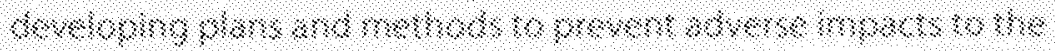

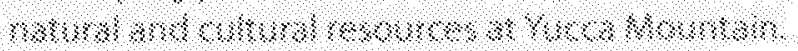

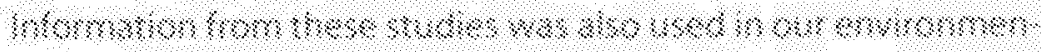

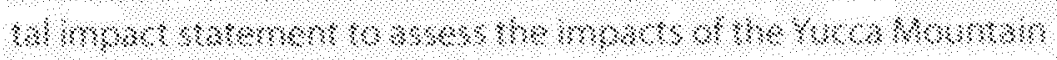

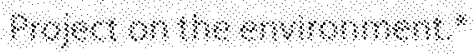

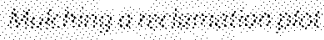

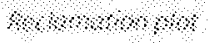

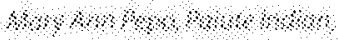

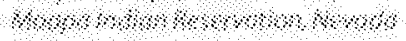

њ

\%ै।

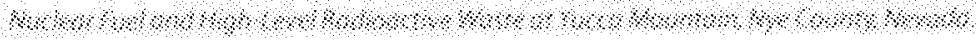

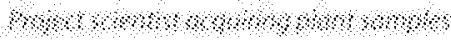




\section{Land Stewardship}

Stewardship of land resources is accomplished through a program based on minimizing the land area that is disturbed by Project activities, managing activities and disturbed sites to reduce and prevent additional impacts, and then restoring disturbed areas to their former natural state when Project activities are completed. Through this program, our scientists preserve and protect the threatened desert tortoise and its habitat, cultural resources, air quality, and water resources.

The reclamation program is part of our land stewardship efforts and involves restoring native vegetation on disturbed areas. Our scientists use methods based on reclamation studies conducted at Yucca Mountain. The Project has already successfully restored disturbed areas and will continue these efforts throughout the life of the Project.

\section{Cultural Resources}

The Yucca Mountain Project is committed to protecting the archaeological and historic resources located within the Yucca Mountain area. Our Cultural Resources Management program has two components: an Archaeology program and a Native American Interaction program.

The purpose of our Archaeology program is to identify, protect, and preserve cultural and historic sites in the Yucca Mountain area. Our major goal is to preserve the artifacts of those that came before us.

The Native American Interaction program was initiated in 1987 to protect the area's cultural resources.
This program promotes information exchange among 17 tribes and organizations from Nevada, Utah, Arizona, and California. The program provides ways for the tribes to keep us informed of their cultural and environmental concerns and for us to inform the tribes of Project plans and activities.

\section{Pollution Prevention and Waste Minimization}

Pollution prevention seeks to minimize waste and impacts to natural resources, use alternative energy, and promote environmental awareness among Yucca Mountain Project employees. Our goals are to minimize waste, reduce the use of non-renewable resources, and identify and use environmentally safe products whenever possible.

Employees are trained to place a high priority on environmental issues and to incorporate pollution prevention goals into project planning and daily work activities.

\section{Waste Management}

Although we strive to minimize the amount of waste generated by Project activities through the Pollution Prevention program, not all waste can be eliminated. Our Waste Management program ensures that we properly manage and dispose of hazardous and nonhazardous waste according to state and federal laws. This helps prevent pollution and ensures the safety and health of our workers and the public.

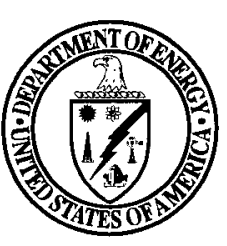

U.S. Department of Energy

Office of Civilian Radioactive Waste Management

\section{Yucca Mountain Project}

1551 Hillshire Dr.
Las Vegas, NV 89134
$1-800-225-6972$
http://www.ocrwm.doe.gov
DOE/YMP-0116
February 2005

